\title{
A Study of Closure of Tympanic Membrane Perforation by Potassium Carbonate $\left(\mathrm{K}_{2} \mathrm{CO}_{3}\right)$ Cauterisation
}

\author{
Gangaprasad A Waghmare* \\ K G Mittal Ayurved College, India
}

Submission: November 01, 2017; Published: December 01, 2017

*Corresponding author: Gangaprasad A Waghmare, K G Mittal Ayurved College, Tel: +919096566633; Email: drgw007@gmail.com

\section{Introduction}

Tympanic Membrane Perforation is Common in Otolaryngological Practice. Perforation of tympanic membrane is categorized into acute\& chronic. Traumatic perforations of tympanic membrane are often encountered as emergency \& in primary care setting. A perforated tympanic membrane results in loss of hearing due to decreased drum area \& liability to recurrent infection of middle ear mucosa. Surgical closure of tympanic membrane perforation still remains the choice of management, effective closure of tympanic membrane perforation can be achieved using chemical cautery. In Ayurveda "Sushrutacharya (Ancient Surgeon/father of Surgeon)" has mentioned the importance of "Potassium carbonate (K2CO3)" in the name of "Yavakshar" in different diseases. A 52 year old lady who underwent this mode of treatment as simple office procedure is discussed in this article [1-6].

\section{Case Report}

A Hindu, married, 52 year old lady patient visited (August $22,2017)$ the outpatient department of ENT with OP Number 201716317 for the complaint of Ringing noise, Earache, difficulty in hearing in left Ear. There was a history of being slapped on left ear one day before her first visit. Her vital signs were normal. She was Afebrile, not pale. Abdomen was full \& move with respiration. There was no palpable peripheral lymph nodes. The chest was clear with good air entry \& Heart sound were normal. Both pinnae appeared normal. Otoscopy of left ear External auditory meatus revealed ecchymosis around the wall of tympanic membrane with fresh central perforation of about $25-30 \%$ in the pars tensa with irregular margins. Rinnes test was negative in left ear \& webers test lateralised to left ear. Audiogram done on following day showed conductive hearing loss of $20 \mathrm{db}[7,8]$.

Potassium carbonate $\left(\mathrm{K}_{2} \mathrm{CO}_{3}\right)$ is a white salt, soluble in water which forms strongly alkaline solution. Yavakshar is made with whole plant of barley (Hordeum Vulgare). Whole plant is dried, burnt in open air, ash is added with water, left over night. sedimented portion is discarded clear liquid is filtered many times. After getting a clear liquid, it is heated and solid powder which is left over at the bottom of the vessel is called as Yavakshar. The technique was carried out as an OP procedure. For the initial application, 4\% xylocaine was used to anaesthetize the tympanic membrane by adding a few drops into a small cotton ball \& placing it into external canal wall over the surface of tympanic membrane for about $5 \mathrm{~min}$, while subsequent application did not require local anaesthesia [9].

The rim of the perforation was cauterized using a cotton tip applicator dipped in liquid form of Potassium carbonate (K2CO3) care was taken not to scar the promontory. The patient was evaluated on every 7 th day \& the technique was repeated for a five times. On the second follow up, the patient reported reduction in the symptom of Otalgia. Ringing in ear was seen once in 4 days or occasionally. Improvement was observed in Hearing loss. Marked improvement was seen in healing of perforated Tympanic membrane from second setting of cauterization. The patient was on follow up till five weeks, without any single episode of relapse [10].

\section{Discussion}

Perforation of tympanic membrane causes a conductive hearing loss that can range from negligible to $50 \mathrm{db}$. Local application of Potassium carbonate $\left(\mathrm{K}_{2} \mathrm{CO}_{3}\right)$ at the site of perforation causes irritation which in lead helps in de-epithelisation process. Histopathological study of newly form perforation shows proliferation of squamous epithelium within $12 \mathrm{~h}$ at the edge of perforation, granulation formation within $18 \mathrm{~h}$, while the inner mucosa of the membrane takes several days to regenerate. The principle of chemical cauterization is that when on application, it breaks up fibrosis, promotes granulation \& new tissue formation at the margins of perforation.

\section{Conclusion}

Based on clinical signs \& symptoms and on Otoscopic examination of healed Tympanic membrane, it may be consider as a first line in the management of small to moderate size perforation before attempting surgical closure. Apart from the fact that multiple sitting is required which is a disadvantage, this procedure of cauterization by Potassium carbonate $\left(\mathrm{K}_{2} \mathrm{CO}_{3}\right)$ is a relatively safe, 
simple \& economical technique. As it can be done as an office procedure with minimal sophisticated equivalents.

\section{References}

1. Alxender Rosinkin, VT Palchun, NL Voznesenky (2013) Diseases of Ear, Nose and throat, MIR Publishers, Russia.

2. Venimadhav shastri Joshi (1968) Ayurvediya Shabdakosha, Maharashtra Rajyasahitya and Sanskruti Mandal, India.

3. KB Bhargava (2000) Short text book of ENT Diseases. Usha Publications, Gopal bhavan, Tagore Road, Mumbai, India.

4. Simson Hall, Barnard H, Colman Churchill (1981) Diseases of Ear, Nose and throat. Livingstone, Robert Stevension, Edinburgh, Scotland.

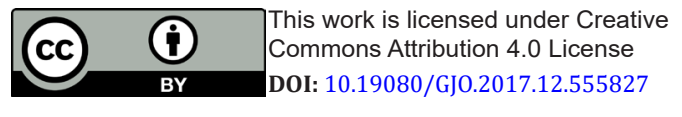

5. PL Dhingra (1998) Diseases of Ear, Nose and throat. BI Churchill Livingstone, Janapath, New Delhi, India.

6. (1994) Yadavaji Trikamji Acharya, Dalhan, Nibandha Sangraha comm. on Sushruta, Chaukhambha Sanskrit Sansthan, Varanasi, India.

7. (1970) Kaviraj Ambikadatta Shastri Vidyotini Hindi Comm Edited by shri Rajeshwar Datta Shastri Bhaishajya Ratnavali-Choukhambha Sanskrit Sansthan, Varanasi, India.

8. Yadavjitrikamjiaachrya, Ayurned Deepika (1941) Chakrapani data comm. On-Charak Samhita, Nirnaya Sagar Press, Mumbai, India.

9. B K Mahajan (1999) Methods in Biostatistics, Jaypee Brothers Medical Publishers Pvt. Ltd. Dariyaganj, New Delhi, India.

10. Acharya Priyawat Sharma, Dravya Guna Vignyana, Published By Chaukhambha Bharti Acadamy, Varanasi, India.

\section{Your next submission with Juniper Publishers} will reach you the below assets

- Quality Editorial service

- Swift Peer Review

- Reprints availability

- E-prints Service

- Manuscript Podcast for convenient understanding

- Global attainment for your research

- Manuscript accessibility in different formats ( Pdf, E-pub, Full Text, Audio)

- Unceasing customer service

Track the below URL for one-step submission https://juniperpublishers.com/online-submission.php 